\title{
Determinants of Microcredit Loan Repayment of Microfinance Institutions in Trincomalee District
}

$$
\text { by }
$$

Diluxshy Ravichandran

M.Sc. 


\title{
Determinants of Microcredit Loan Repayment of Microfinance Institutions in Trincomalee District
}

\author{
by \\ Diluxshy Ravichandran
}

A thesis submitted to the University of Sri Jayewardenepura in partial fulfillment of the requirements for the Degree of Master of Science in Management on 2016. 


\section{Declaration by the candidate}

"The work described in this thesis was carried out by me under the supervision of Dr. P.

J. Kumarasinghe and a report on this has not been submitted in whole or in part to any university or any other institution for another Degree/ Diploma".

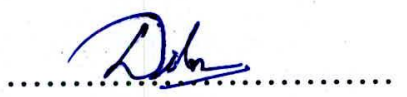

Diluxshy Ravichandran 


\section{Certification}

"I certify that the above statement made by the candidate is true and that this thesis is suitable for submission to the University for the purpose of evaluation".

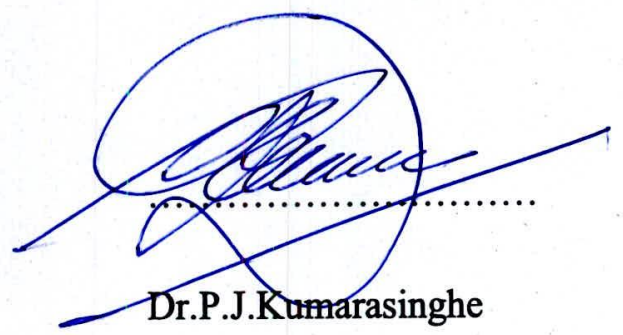

0.5 .106 .12016

Date 


\section{Table of Contents}

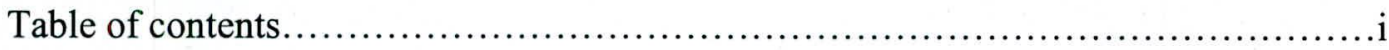

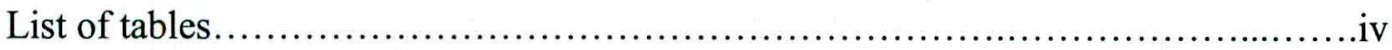

List of figures.........................................................................

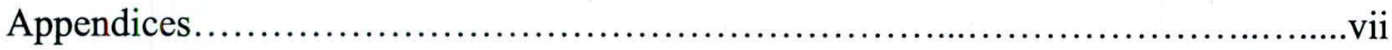

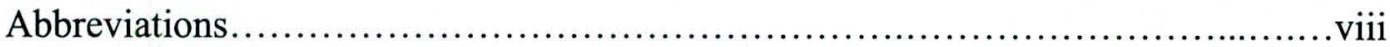

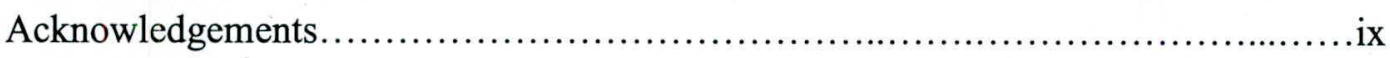

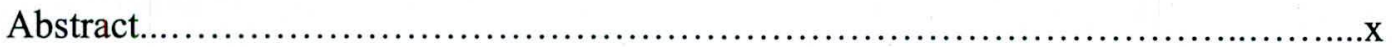

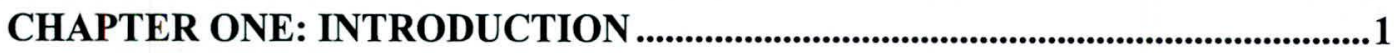

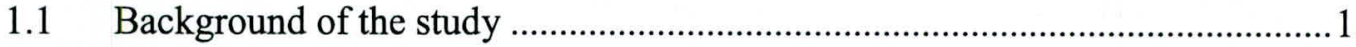

1.2 Identification of the research problem...........................................................

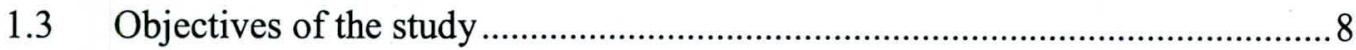

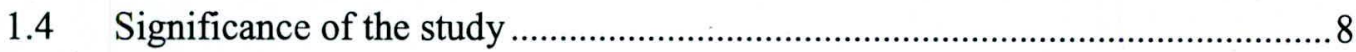

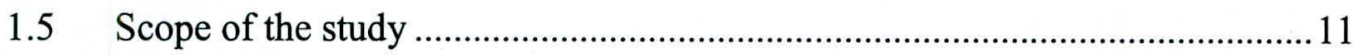

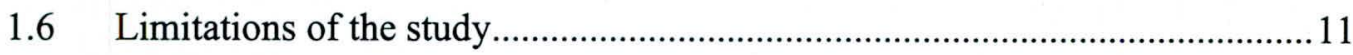

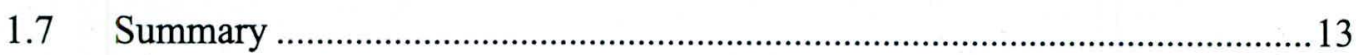

CHAPTER TWO: LITERATURE REVIEW .........................................................14

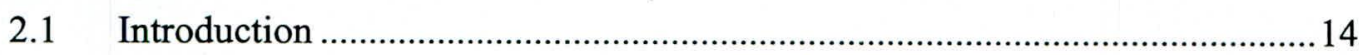

2.2 Definition of Microfinance.......................................................................... 14

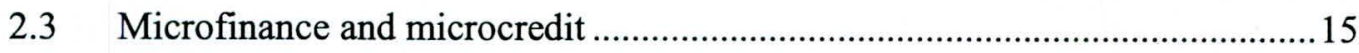

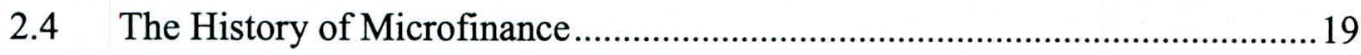

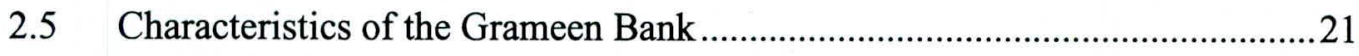

2.6 Microfinance and its impact in development .................................................2

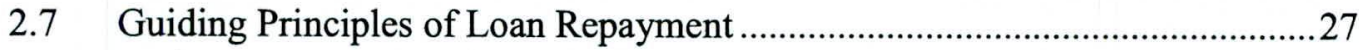

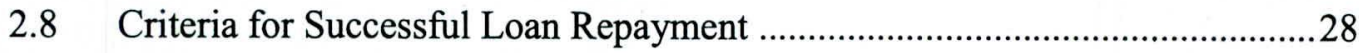

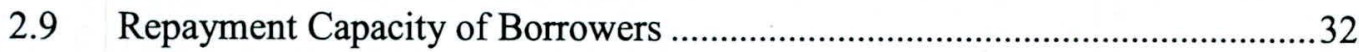

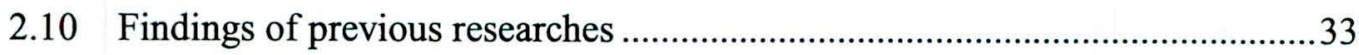

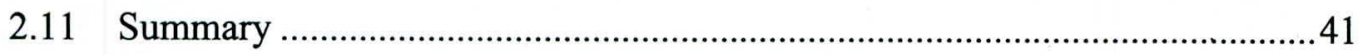




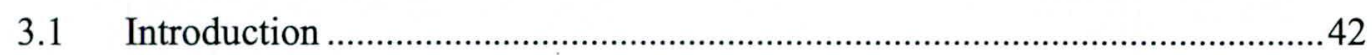

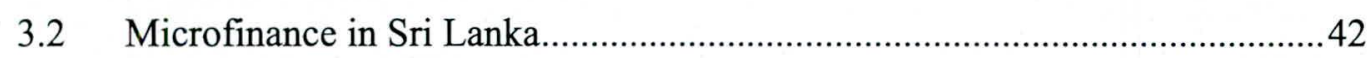

3.2.1 Regulation of the Microfinance Sector in Sri Lanka ...............................46

3.2.2 Nature of Microcredit lending system in Sri Lanka..................................48

3.2.3 Microfinance Providers in Sri Lanka .......................................................5

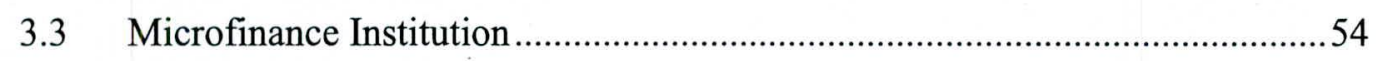

3.4 Overview of selected finance companies ........................................................5

3.4.1 Commercial Credit \& Finance PLC ...........................................................57

3.4.2 Nation Lanka Finance PLC .....................................................................6 60

3.4.3 Berendina Microfinance Institute (Guarantee) Ltd (BMI) .......................60

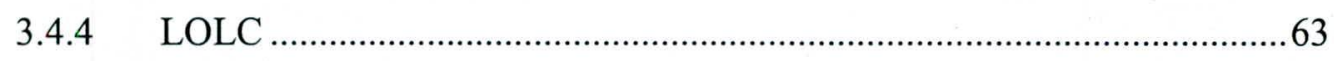

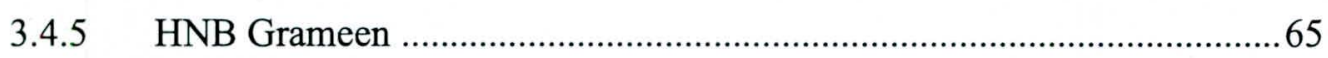

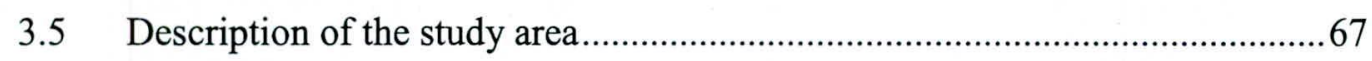

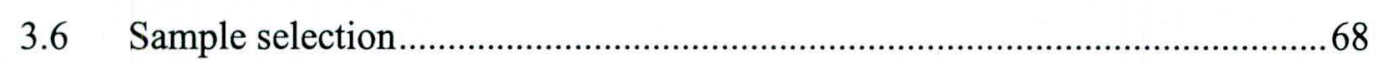

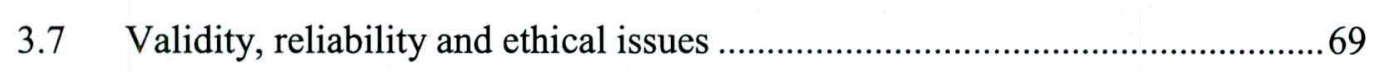

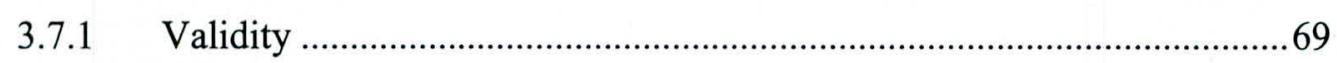

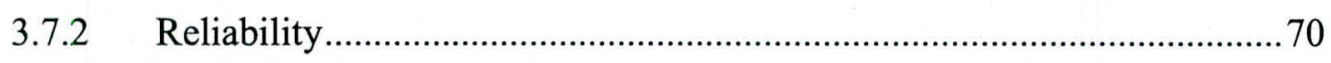

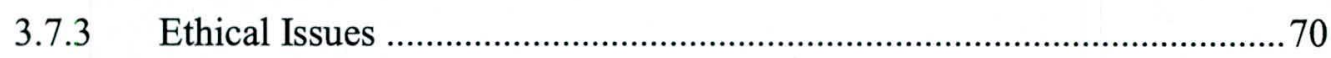

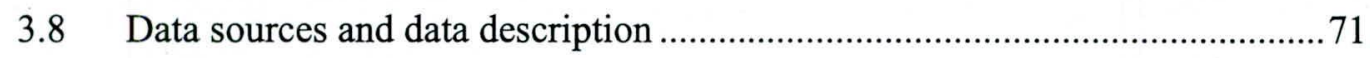

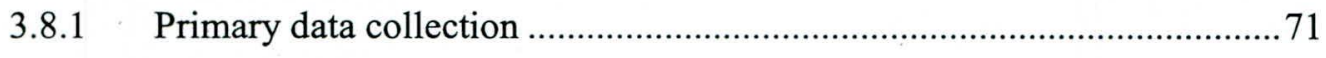

3.8.2 Secondary data collection ................................................................ 73

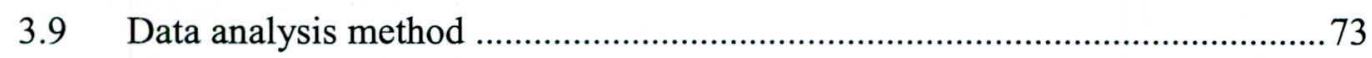

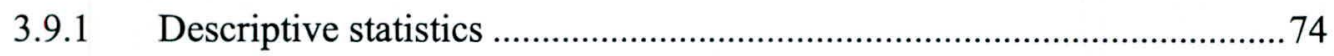

3.9.2 Correlation Analysis ........................................................................... 74

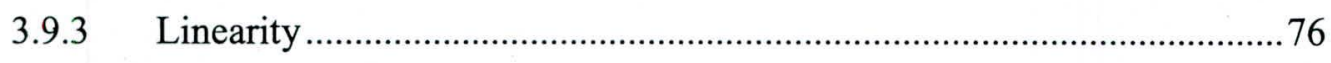

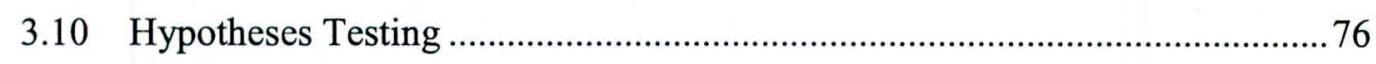

3.11 Determinants of the loan repayment .......................................................... 76

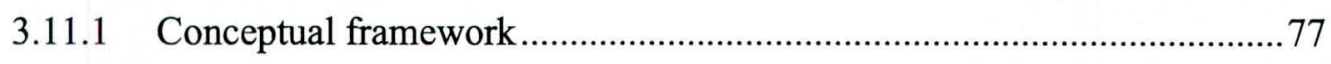

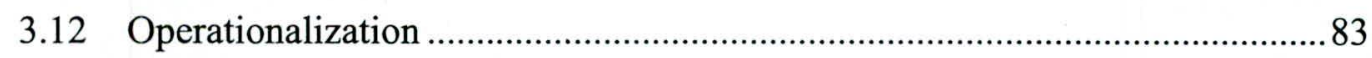

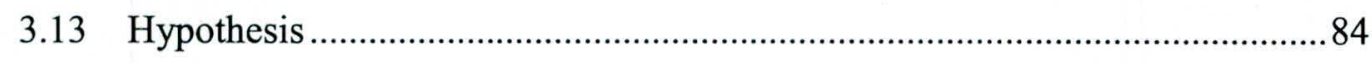

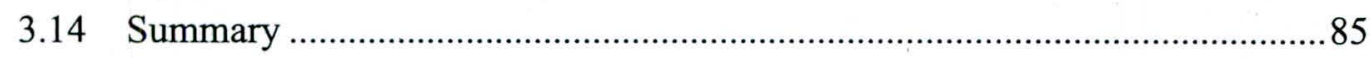




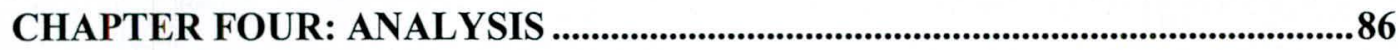

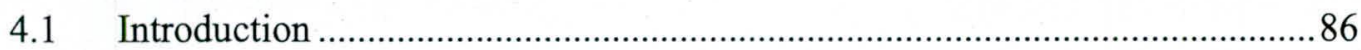

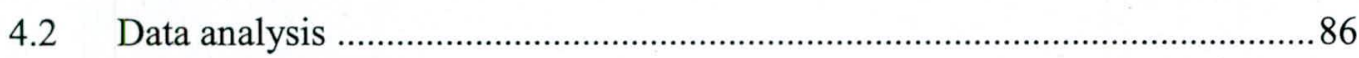

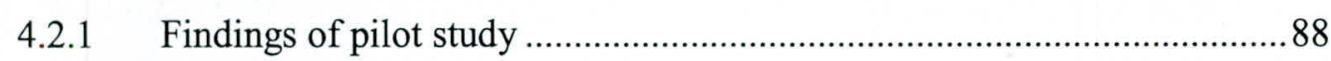

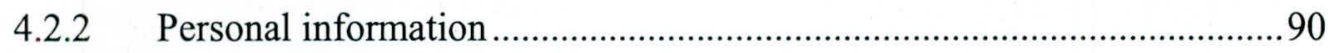

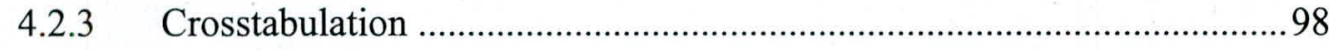

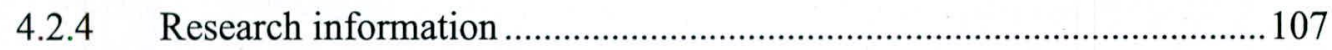

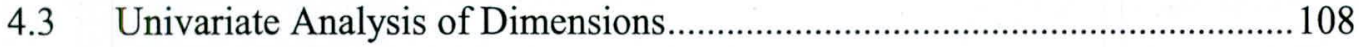

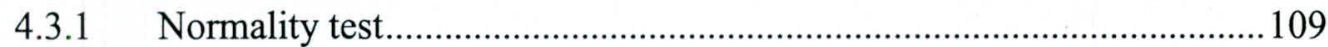

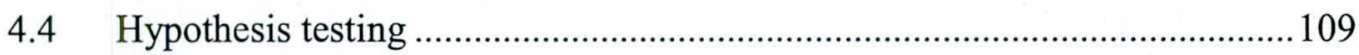

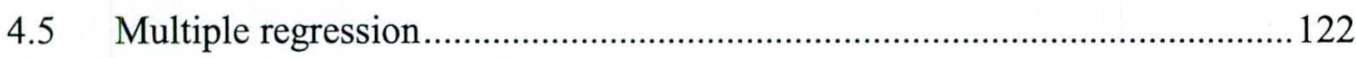

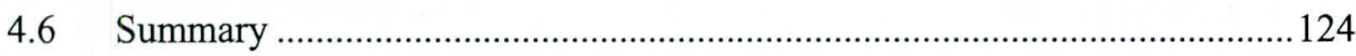

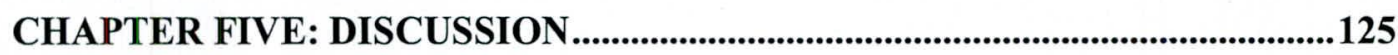

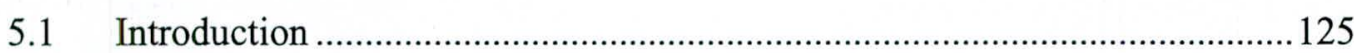

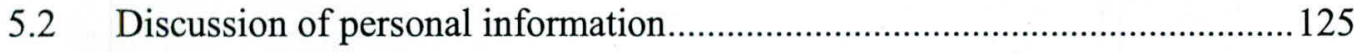

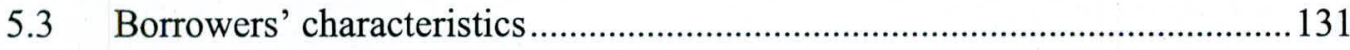

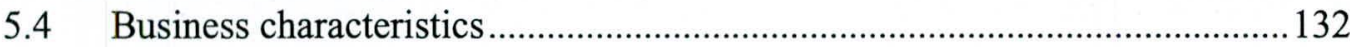

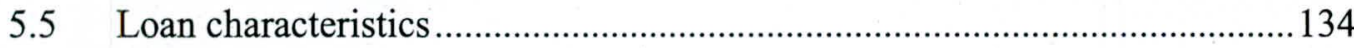

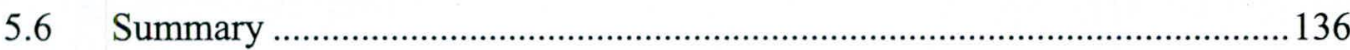

CHAPTER SIX: CONCLUSIONS........................................................................137

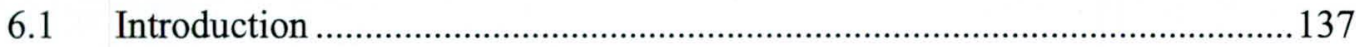

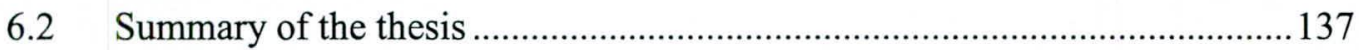

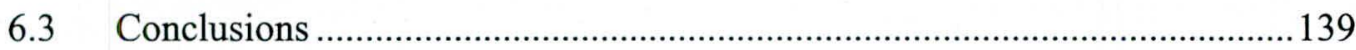

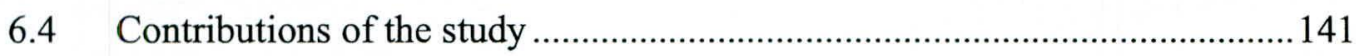

6.5 Directions for future research................................................................... 141

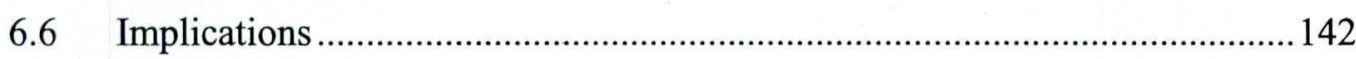

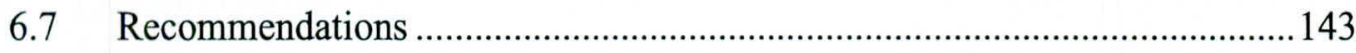

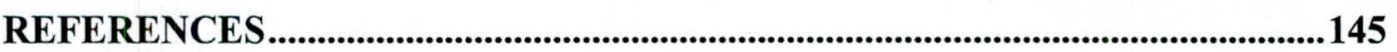

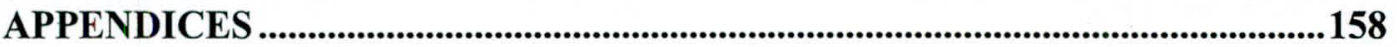




\section{List of tables}

Table 1-1 Loan repayment rates .............................................................................. 7

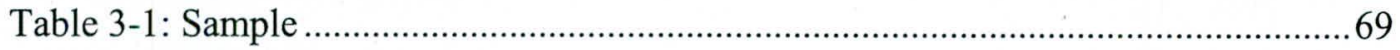

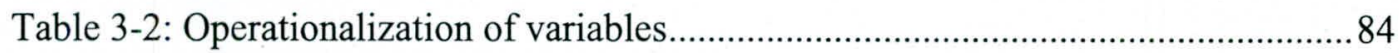

Table 4-1: Cronbatch alpha value of microcredit loan repayment factors.......................8 88

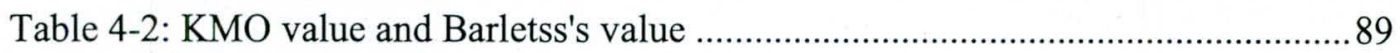

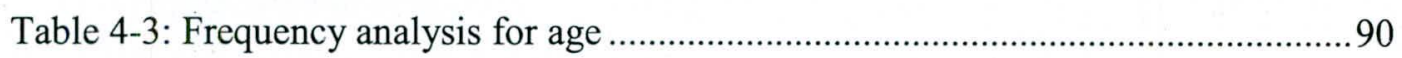

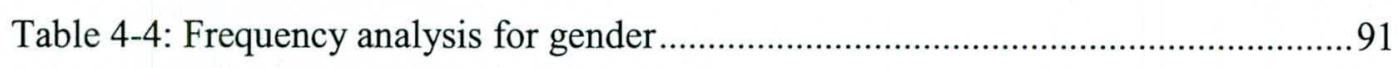

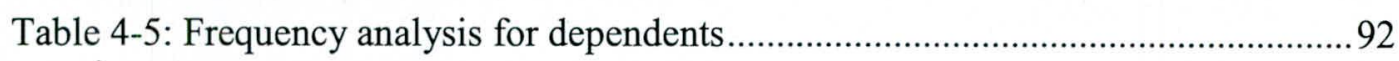

Table 4-6: Frequency analysis for educational qualification .........................................93

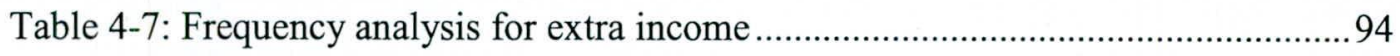

Table 4-8: Frequency analysis for type of business ......................................................95

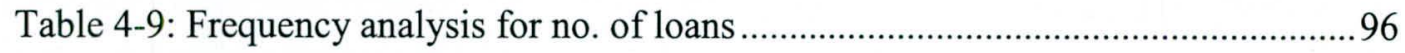

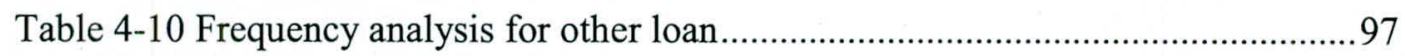

Table 4-11: Cross tabulation of age and repayment .................................................. 99

Table 4-12: Cross tabulation of gender and repayment .............................................. 100

Table 4-13 Cross tabulation of dependent and repayment............................................101

Table 4-14: Cross tabulation of educational qualification and repayment ....................102

Table 4-15: Cross tabulation of business type and repayment ................................... 104

Table 4-16: Cross tabulation of multiple loan and repayment.....................................105

Table 4-17: Cross tabulation of extra income and repayment ...................................... 107

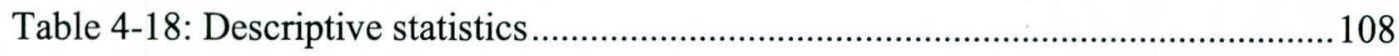

Table 4-19: Independent sample t test for borrowers' characteristics of paid and non

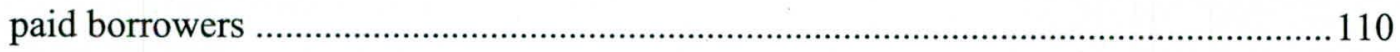

Table 4-20: Independent sample t test for business characteristics of paid and non paid borrowers

Table 4-21: Independent sample t test for loan characteristics of paid and non paid borrowers

Table 4-22: Independent sample t test for responsiveness of borrowers and repayment

Table 4-23: Independent sample t test for intention of borrowers and repayment 114 
Table 4-24: Independent sample $t$ test for knowledge of borrowers and repayment....115

Table 4-25: Independent sample $t$ test for utilization and repayment...........................116

Table 4-26: Independent sample $t$ test for continuity and repayment...........................117

Table 4-27: Independent sample $t$ test for profitability and repayment........................118

Table 4-28: Independent sample $t$ test for risk and repayment .................................... 119

Table 4-29: Independent sample $t$ test for terms of loan and repayment....................... 120

Table 4-30: Independent sample $t$ test for eligibility of borrowers and repayment ...... 121

Table 4-31: Loan repayment and borrowers' characteristics, business and loan

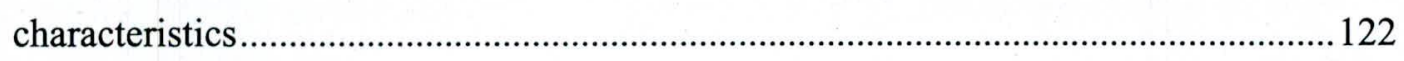

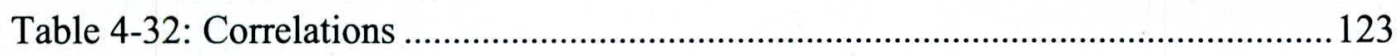




\section{List of figures}

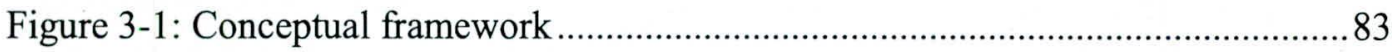

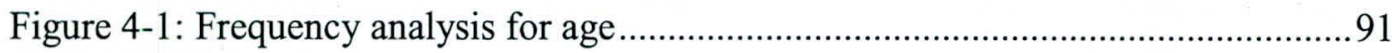

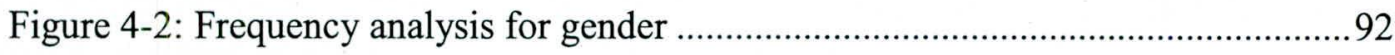

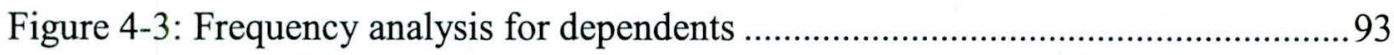

Figure 4-4: Frequency analysis for educational qualifications ...................................94

Figure 4-5: Frequency analysis for extra income …................................................ 95

Figure 4-6: Frequency analysis for type of business ................................................96

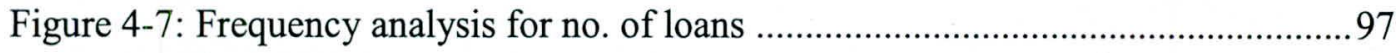

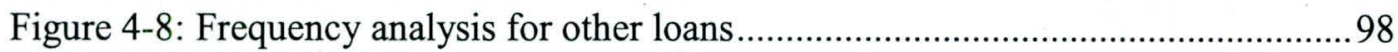

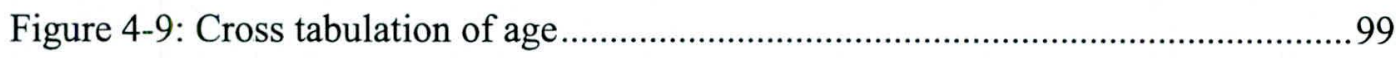

Figure 4-10: Cross tabulation and repayment …................................................... 100

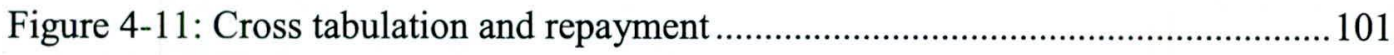

Figure 4-12: Cross tabulation for educational qualification and repayment..................103

Figure 4-13: Cross tabulation for business type and repayment................................104

Figure 4-14: Cross tabulation for multiple loan and repayment .................................106

Figure 4-15: Cross tabulation for extra income and repayment...................................107 


\section{Appendices}

$\begin{array}{lll}\text { Appendix I } \quad \text { Map of Trincomalee District } & 158\end{array}$

$\begin{array}{lll}\text { Appendix II Covering letter for data collection-I } & 159\end{array}$

$\begin{array}{lll}\text { Appendix III Covering letter for data collection-II } & 160\end{array}$

$\begin{array}{lll}\text { Appendix IV Institutional questionnaire } & 161\end{array}$

$\begin{array}{lll}\text { Appendix V } & \text { Participant questionnaire } & 164\end{array}$ 


\begin{tabular}{ll} 
Abbreviations & \\
MFIs: & Microfinance Institutions \\
PLC: & People Leasing Company \\
Pvt: & Private limited \\
HNB: & Hatton National Bank \\
LOLC & Lanka Orix Leasing Company \\
LOMC & Lanka Orix Leasing Company Microfinance Company \\
CBSL & Central Banka of Sri Lanka \\
CGAP & Consultative Group to Assist the Poor \\
TCCS & Thrift and Credit Co-operative Societies \\
MPCS & Multi- Purpose Co-operative Societies \\
RRDB & Regional Rural Development Banks \\
RDB & Regional Development Banks \\
NGO & Non-Government Organizations \\
CBSL & Central Bank of Sri Lanka \\
SBS & Samul Bank Societies \\
\hline
\end{tabular}




\section{Acknowledgements}

First and foremost, I thank GOD for blessing me with the opportunity to pursue my M.Sc in Management at University of Sri Jayewardenapura and for giving me the strength and guidance to complete it.

I would like to extend my utmost gratitude to the Supervisor and Coordinator of MBA/MPM/M.Sc. Programme, Dr. P. J. Kumarasinghe for his support, guidance, understanding and dedication with encouragement throughout the whole process and the theme of the thesis. He kindly read articles and offered invaluable detailed advice on organization.

To Senior Professor (Mrs.) Swarna Piyasiri, Dean, Faculty of Graduate Studies, University of Sri Jayewardenepura, as well as all the other professors and lecturers who taught me over the past years. This thesis is made possible through the help and support from everyone, including: Senior Lecturers, my family members and friends.

Finally, I sincerely thank all Microfinance Institutions' Managers and staff who provided the advice and support for a meaningful collection of data. The product of this thesis would not be possible without all of them.

Researcher. 


\begin{abstract}
The microcredit loans are able to improve the economic and social status of the poor since it provides a working opportunity. Apart from the challenges to reaching out to the poor in offering microcredit loans, the microfinance institutions especially subsidized microfinance institutions also have a challenge with loan repayment. The high default rate has affected the sustainability of the micro-credit initiatives. This study investigates the determinants of loan repayment problems among microfinance borrowers. The main objective of the research was to find out the causes of microcredit loan repayment within Microfinance institutions in Trincomalee District. The research framework of this study is built by three independent variables namely borrowers' characteristics, business characteristics and loan characteristics and repayment both paid on time and not paid as dependent variables. The target population comprised a total of 9200 loan borrowers out of which a sample of 100 was picked using stratified simple random sampling, which enabled every member of the population to have an equal and independent chance of being selected as respondents and also the simplest, most convenient and bias free selection method. The data was collected by use of self developed questionnaire issued to the microcredit borrowers, in depth interviews had with microcredit group leaders and MFIs' Manager and staff. The data was analyzed by using statistical software (SPSS 21) and tabulated by use of tables and figures. The findings revealed that most borrowers did not spend the loan amount on the intended and agreed purpose. The study found out that loan repayment default was a result of inadequate returns to repay the loan and the findings further, indicate unfavourable loan product's characteristics designed by the microfinance institutions also as a reason for loan repayment default.
\end{abstract}




\section{CHAPTER ONE INTRODUCTION}

\subsection{Background of the study}

Microfinance has been recognized as an essential socio-economic and financial mechanism for poverty alleviation, promoting entrepreneurial development and increasing the profile of disadvantaged people in numerous countries throughout the world (Hossain et al. 2012). Microfinance serves to promote rural livelihoods and urban poor by the creation of entrepreneurship opportunities that encourage the elimination of unemployment by creating potential business based on their interest and skill. Microfinance targets to poor people because these people usually have lack of collateral, no steady employment and verifiable credit history, which therefore, cannot even meet the most minimal qualifications to gain access to normal banking. Besides, it can avoid poor people dealing with illegal banking such as moneylenders or loan sharks who charge an unreasonable interest rate.

Poverty is a major economic problem in Sri Lanka and hence various poverty alleviation programmes have been implemented by successive governments in the past. However, eradication of poverty is not possible either by providing food subsidy or by creating job opportunities. According to Yunus (1999), the poor can be saved by providing them an opportunity to realize their potentials. He has pointed out that poor are poor not because they are lazy, untrained or illiterate but because they cannot earn genuine returns on their labour. Therefore, creating opportunities and empowerment of the poor could be considered as the way to end poverty (Bhatt 1998, Yunus,1999). 